Ann. Biol. anim. Bioch. Biophys., 1977, 17 (4), 539-542.

\title{
Nutritional and circadian variations in lipase activity and colipase saturation in rat pancreas
}

par Anik GIRARD-GLOBA, Elizabeth SIMOND-COTE.

Centre de Recherches sur la Nutrition - C.N.R.S.,

92190 Meudon Bellevue, France

Our laboratory has already shown a nycthemeral rhythm in pancreatic protein synthesis as well as in chymotrypsinogen and amylase content. However, the problem of variation in lipase activity is more complex since colipase has to be taken into account in assessing physiological lipase activity (Maylie et al., 1971 ; Borgström and Erlanson, 1971). One purpose of this study was to determine if lipase follows the same pattern as the other hydrolases in the pancreas, and whether variations in colipase are systematically parallel to those of lipase content, $i$. e. is the degree of colipase saturation of lipase always the same. Our other aim was to ascertain if colipase responds to nutritional changes to the same extent as lipase does (Bücko and Kopec, 1968 ; Gidez, 1973). Since we could not actually determine colipase because a sufficient supply of colipase-free lipase was not available, the degree of saturation was estimated by adding increasing amounts of a crude exogenous preparation of colipase.

\section{Material and methods.}

Rats weighing $100 \mathrm{~g}$ at the beginning of the experiment were fed ad libitum diets containing either 70 p. 100 starch, 70 p. 100 sucrose or 41 p. 100 lard, and providing an identical daily intake of 62 calories and $3.3 \mathrm{~g}$ casein. Three different levels of lipase activity were obtained under these conditions. After 4 weeks on the experimental diets, 8 rats in each group were killed every 3 hrs over a 24-hour period. The pancreas was excised and quick-frozen.

Lipase content was determined on 10 p. 100 homogenates under various conditions to assess both physiological and total lipase activities. Lipase activity was first determined at $\mathrm{pH} 8.2$ on a trioleate substrate in presence of deoxycholate $(0.75 \mathrm{p} .100)$ $\mathrm{CaCl}_{2}(0.2 \mathrm{mM})$ and $\mathrm{NaCl}(75 \mathrm{mM})$. Since the reaction under these conditions was colipase-dependent, the activity of the lipase-colipase complex was measured as it exists in the tissue. Secondly, the same reaction was added to saturation with crude exogenous colipase (prepared by precipitation of the proteins at $\mathrm{pH} 2$ ) to assess the degree of colipase saturation in the tissue. 


\section{Results.}

Apparent lipase activity (oleate substrate) responded to diet as expected (fig. 1). Mean daily activity was $\mathbf{8 . 1}$ units per $g$ tissue with the lard diet as compared to 4.0 for starch and 1.75 for sucrose. Nycthemeral variations were similar to those of the other enzymes with a period of progressive accumulation from 9:00 hours to 15:00 hours., and a nocturnal maximum between $21: 00$ hours and 3:00 hours.
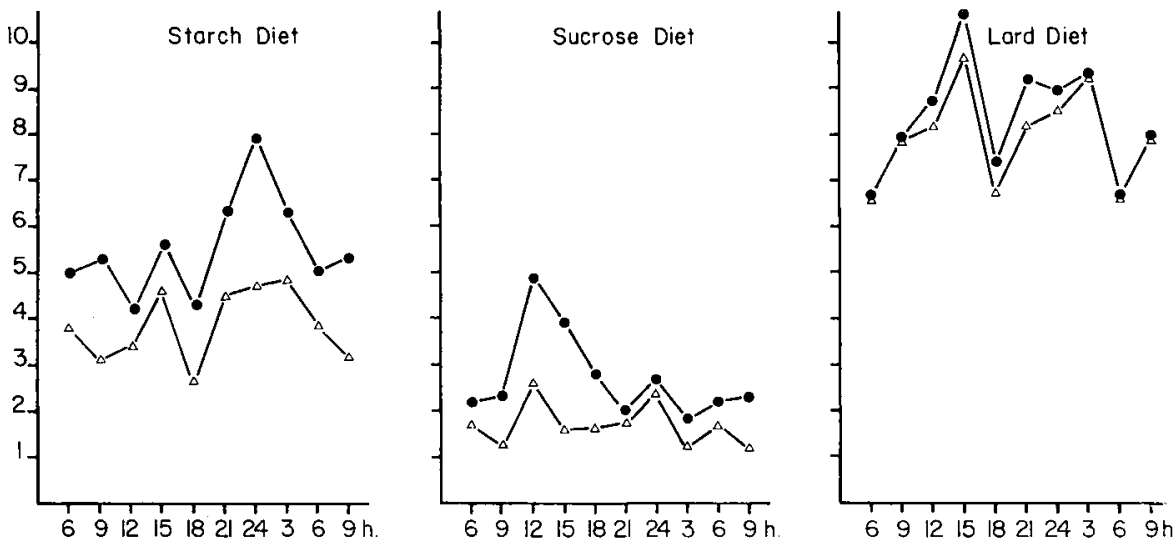

FIG. 1. - Circadian variations of apparent and potential lipase activity in pancreatic tissue, expressed as $m$ moles ocid produced per min per $g$ tissue.

Apparent lipase $(\Delta-\Delta)$ was determined on a substrafe of emulsified triolein in the presence of $\mathrm{mMCa}, 2 \mathrm{p} .100$ deoxycholate, at pH 8.2. Potential activity was obtained by saturating the incubation medium with excess exogenous colipase.

$\Delta$ Apparent (oleate).

- Potential (oleate + colipase).

The addition of a saturating a mount of colipase to each incubation medium resulted in changes in lipase activity affecting both the different groups and the different time points to a variable extent (fig. 1). Mean values for total lipase activity in the

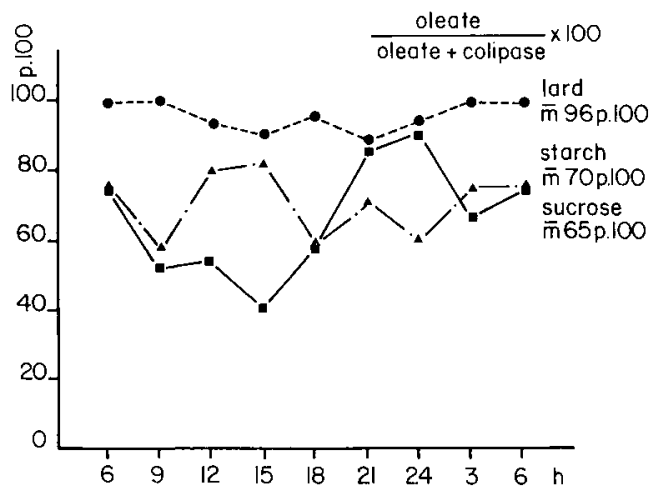

FIG. 2. - Apparent lipase activity expressed as percent of pofential. 
starch-fed group were 5-6 units per g tissue, a 40 p. 100 rise over apparent activity. In the sucrose-fed group, mean total lipase was 2-8 units per $g$ tissue, 57 p. 100 over potential. Finally, in lard-fed animals, it only reached 8.5 units per g tissue, i. e. 5 p. 100 higher than apparent lipase. The differences in the course of the nycthemeral period appear more clearly in figure 2 where apparent lipase is expressed as a percentage of the total. In lard-fed subjects, apparent activity was uniformly between 90 and $100 p$. 100 of potential. By contrast, in the other two groups the ratio varied according to the time of day and differently with the two diets. Thus, in starch-fed animals apparent lipase was closest to potential in the interprandial period (9:00 - 12:00) with values up to 80 p. 100 and lowest during the feeding time ( 45 to 60 p. 100 of potential). On the contrary, in sucrose-fed subjects, the difference was greatest in the interprandial period when potential lipase was as low as 40 p. 100 of the total and smallest during itia prandial phase with values of the order of 90 p. 100.

\section{Discussion.}

Not presuming the fotal amount of colipase present in the tissue, the first conclusion to be drawn from these experiments is that the diet strongly influences colipase saturation of lipase. In carbohydrate-fed rats (starch or sucrose), apparent lipase activity of the lipase-colipase complex, as it exists in the tissue, presents only 65 to 70 p. 100 of the total activity revealed by colipase saturation. On the other hand, in lipid-fed subjects, the adaptation concerns not only lipase itself but also colipase since the degree of saturation is consistently of the order of 90 to 100 p. 100.

There is a nycthemeral rhythm in potential lipase activity of the pancreatic tissue, parallel to that of other hydrolases such as chymotrypsinogen and amylase, and independent from the type of energetic substrate fed. Since lipase-colipase saturation in lard-fed animals is constantly close to 100 p. 100 there is no difference between apparent and total lipase during the course of the nycthemeral period. However, in carbohydrate-fed animals colipase saturation of the enzyme varies widely and differently during the day. With the starch diet, saturation is lowest at night with only enough colipase to express 60 p. 100 of total activity. It is highest between 12:00 and 15:00 hrs with 80 p. 100 saturation. However, in saccharose-fed subjects, saturation is close to 90 p. 100 during feeding time while it is as low as 40 p. 100 during fasting $(15: 00 \mathrm{hrs})$. Saturation in these carbohydrate-fed rats varies inversely with total lipase content. Therefore, without presuming actual colipase content, pancreatic tissue colipase may be less variable than lipase.

Opposite rhythms in total lipase activity of pancreas from animals fed carbohydrates or lipids again raise the question of the nature of the information responsible for lipase synthesis. It is interesting to note that, although apparent lipase activity follows the same pattern as other hydrolases, the same cannot be said of total lipase. In many respects, lipase seems to evidence specific behavior.

In conclusion, in this report we have demonstrated a nycthemeral rhythm in the lipase content of pancreatic tissue and have also shown that colipase adapts to diet composition. In animals fed a high fat diet, lipase and colipase are both elevated. There is either an excess of colipase with respect to lipase, or else it follows closely lipase 
variation. With carbohydrate diets, colipase plays an important role in the regulation of actual lipasic activity since it does not vary in parallel with lipase.

Commission CNERNA Digestion-Absorption, Tours, 13 novembre 1976.

Résumé. Le régime influence fortement la saturation de lipase en colipase. Chez le rat nourri d'un régime glucidique (amidon ou glucose) l'activité apparente de la lipase représente seulement 65 à $70 \mathrm{p} .100$ de l'activité lipasique potentielle obtenue après saturation par de la colipase. En revanche, chez l'animal nourri d'un régime lipidique, il est montré que la colipase, comme la lipase s'adapte aux lipides puisque le degré de saturation déterminé varie entre 90 et 100 p. 100 .

Il existe un rythme nycthéméral de l'activité de la lipase potentielle parallèle à celui des autres hydrolases et indépendant du type de substrat énergétique alimentaire. II semblerait cependant que la teneur en colipase du tissu pancréatique varie moins que celle de la lipase.

\section{Références}

BORGSTRÖM B., ERLANSON C., 1971. Pancreatic juice colipase : physiological importance Biochim. biophys, Acta, 242, 509-513.

BÜCKO A., KOPEC Z., 1968. Adaptation of enzymes of the rat pancreas on altered food intake. Nutr. Diet., 10, 276-287.

GIDEZ L. 1., 1973. Effect of dietary fat on pancreatic lipase levels in the rat. J. Lipid Res., 14, 169-177.

MAYLIE M. F., CHARLES M., GACHE C., DESNUELLE P., 1971. Isolation and partial purification of pancreatic colipase. Biochim. biophys. Acto, 229, 286-289. 